\title{
Regulation of bcl-2 family in hydrogen peroxide-induced apoptosis in human leukemia HL-60 cells
}

\author{
Jung Eun Lee', Jeongwon Sohn², \\ Jung Hwa Lee ${ }^{1,3}$, Kwang Chul Lee', \\ Chang Sung Son ${ }^{1}$ and Young Chang Tockgo ${ }^{1}$ \\ ${ }^{1}$ Department of Pediatrics and ${ }^{2}$ Department of Biochemistry, \\ Korea University, Seoul, Korea \\ ${ }^{3}$ Corresponding author: Tel, 82-345-412-5095; \\ Fax, 82-345-405-8591; E-mail, leejmd@ chollian.net
}

Accepted 6 March 2000

Abbreviations: PMSF, phenylmethylsulfonyl fluoride; ROS, reactive oxygen species; PS, phosphatidylserine; CHX, cycloheximide

\begin{abstract}
Numerous types of cells have been shown to undergo apoptosis when exposed to oxidant agent such as hydrogen peroxide. In order to understand the functional relationship between the anti- and pro-apoptotic regulatory proteins in the cells under oxidant stress, we have studied the level of expression of apoptosis regulatory proteins, bcl-2 and bax, in human leukemia HL-60 cells. The exposure of HL- 60 cells to different concentrations of $\mathrm{H}_{2} \mathrm{O}_{2}$ for $6 \mathrm{~h}$ resulted in a typical apoptosis of the cells as characterized by flow cytometry, cell cycle analysis, and DNA fragmentation. There was a block in G1 to $S$ transition and apoptotic cells were mainly derived from $S$ and G2 cells. Kinetic study demonstrated that the levels of both bcl-2-mRNA and -protein expression were decreased with the progression of cellular apoptosis whereas the level of bax-mRNA was unchanged but the expressed bax-protein was not detectable. Cycloheximide, a nonspecific translation inhibitor, did not prevent the hydrogen peroxide-mediated apoptosis in HL-60 cells. These results suggest that the regulation of bcl-2, but not of bax are important factor in the oxidative stress-induced apoptosis in HL-60 cells.
\end{abstract}

Keywords: hydrogen peroxide, apoptosis, HL-60 cell, Bcl-2, cell cycle

\section{Introduction}

Apoptosis is an inherent cellular response for an effective cellular disposal against developmental and environmental insult (Kerr et al., 1972). Although apoptosis can be induced by diverse stimuli, an increasing number of evidences suggest that it is induced by common signaling mediators and the reactive oxygen species (ROS) are recognized as one of those candidates. The reasons for this are that UV irradiation or many chemotherapeutic agents increase intracellular hydrogen peroxide levels at the same time while they induce apoptosis, and that cells tend to resist to the apoptosis-inducing agents when cells are pre-treated with antioxidants. (Gardner et al., 1997; Gorman et al., 1997).

Hydrogen peroxide belongs to the ROS and is known to modulate diverse cellular functions in vivo. By producing hydroxyl radicals through the interaction with metal ions near DNA, hydrogen peroxide induces DNA damage. (Ueda et al., 1992). High concentration of hydrogen peroxide induces necrosis and low concentration induces apoptosis (Gardner et al., 1997; Lennon et al., 1991; Ueda et al., 1992). Although apoptosis and necrosis have different impacts on cellular physiology, the cellular response to hydrogen peroxide is continuum from apoptosis to necrosis (Gardner et al., 1997).

HL-60 cells are promyelocytic human leukemia cells that do not express p53, a known pro-apoptotic protein, whereas do express bcl-2, an anti-apoptotic protein (Agarwal et al., 1997; Gong et al., 1993; Shimizu et al., 1996). Bcl-2 is present in inner membrane of nucleus, mitochondria and endoplasmic reticulum (Hockenbery et al., 1993) and known to form a homo- or hetero-dimer with its counter-protein, bax, and their ratio within the cell eventually decides whether the cell takes into apoptotic pathway (Agarwal et al., 1997; Mengubas et al., 1996).

Since apoptosis can be induced differently in a stimulusdependent way in different cells, we investigated the mechanism of hydrogen peroxide-induced apoptosis in human leukemia HL-60 cells by studying whether bcl-2 family has a role in this system.

\section{Materials and Methods}

\section{Cell culture}

The human promyelocytic leukemia $\mathrm{HL}-60$ cell line was purchased from ATCC (American Tissue Culture Collection) and grown in RPMI medium (Gibco BRL Life Technologies) supplemented with $20 \%$ fetal bovine serum, 2 $\mathrm{mM}$ L-glutamine, and antibiotics/antimycotics. Cultures were incubated at $37^{\circ} \mathrm{C}$ in humidified air with $5 \% \mathrm{CO}_{2}$ and kept in logarithmic phase by routine passage every 
3 days.

\section{Phosphatidylserine(PS) exposure}

Cells $\left(1 \times 10^{6}\right)$ were incubated with $0,0.1,0.5,1.5 \mathrm{mM}$ hydrogen peroxide for $6 \mathrm{~h}$ and then harvested. After washing the treated cells with PBS at $4^{\circ} \mathrm{C}$ twice, PS exposure was measured using Annexin-V-Fluos kit (Boehringer Mannheim) according to manufacturer's instructions. Briefly, cell pellets suspended in the labeling solution $(10 \mu \mathrm{l}$ Annexin-V-Fluos labeling reagent in $500 \mu \mathrm{l} \mathrm{HEPES} \mathrm{buffer)}$ were incubated for $15 \mathrm{~min}$ after adding $10 \mu \mathrm{l}$ of propidium iodide solution $(50 \mu \mathrm{g} / \mathrm{ml})$. The reaction was stopped by adding $0.4 \mathrm{ml}$ of incubation buffer (10 mM HEPES/ $\mathrm{NaOH}, \mathrm{pH} 7.4,140 \mathrm{mM} \mathrm{NaCl}, 5 \mathrm{mM} \mathrm{CaCl}_{2}$ ) and then analyzed on flow cytometer (Beckton Dickenson) using CellQuest program. To exclude fluorescence overlapping, cells were stained as the same above method using only propidium iodide and analyzed on flow cytometer.

\section{Cell cycle analysis}

Cells $\left(1 \times 10^{6}\right)$ were incubated with $0,0.1,0.5,1.5 \mathrm{mM}$ hydrogen peroxide for $6 \mathrm{~h}$ and then harvested. After washing the treated cells with $\mathrm{PBS}$ at $4^{\circ} \mathrm{C}$, the cells were fixed in $70 \%$ ethanol $\left(-20^{\circ} \mathrm{C}\right)$ overnight at $4^{\circ} \mathrm{C}$. Cells were collected by centrifugation, washed with PBS and suspended in PBS containing RNase A (final $100 \mu \mathrm{g} / \mathrm{ml}$ ) and propidium iodide (final $40 \mu \mathrm{g} / \mathrm{ml}$ ). After incubation at $4^{\circ} \mathrm{C}$ for $30 \mathrm{~min}$, the DNA content within the cells was measured by flow cytometer (Beckton Dickenson) using CellQuest program and the cell cycle was analyzed using ModFit program.

\section{DNA fragmentation}

The cells $\left(1 \times 10^{6}\right)$ exposed to $0,0.1,0.5,1.5 \mathrm{mM}$ hydrogen peroxide for $6 \mathrm{~h}$, were harvested and centrifuged at $500 \times \mathrm{g}$ for $5 \mathrm{~min}$ at room temperature. Each cell pellet was suspended in the lysis buffer $(0.1 \mathrm{M} \mathrm{NaCl}, 10 \mathrm{mM}$ Tris- $\mathrm{HCl}, \mathrm{pH}$ 8.0, $1 \mathrm{mM}$ EDTA, $\mathrm{pH}$ 8.0) in the presence of $10 \%$ SDS and proteinase $\mathrm{K}(20 \mathrm{mg} / \mathrm{ml})$ and resuspended cells were incubated in shaking incubator at $56^{\circ} \mathrm{C}$ for $2 \mathrm{hr}$. DNA was then extracted with $5 \mathrm{M} \mathrm{NaCl}$ solution, precipitated in ethanol, centrifuged at $12,000 \times$ $\mathrm{g}$ for $30 \mathrm{~min}$, and resuspended in TE buffer. After quantitation of DNA, $2.5 \mu \mathrm{g}$ of each DNA per lane was electrophoresed in an $1.2 \%$ agarose gel for $30 \mathrm{~min}$ at $100 \mathrm{~V}$ and the gel was visualized with ethidium bromide.

\section{mRNA analysis of bcl-2 and bax}

Cells $\left(1 \times 10^{6}\right)$ exposed to $0.5 \mathrm{mM}$ hydrogen peroxide for $0,2,4,6 \mathrm{~h}$. were washed with PBS at $4^{\circ} \mathrm{C}$ twice and homogenized, and RNA was isolated using Tri-reagent (Sigma) according to the manufacturer's instructions. Briefly, after homogenization, cells were collected by centrifugation $\left(12,000 \times \mathrm{g}, 10 \mathrm{~min}, 4^{\circ} \mathrm{C}\right)$. Chloroform was added to clear supernatant and incubated for $10 \mathrm{~min}$ at room temperature. After centrifugation (12,000×g, $\left.15 \mathrm{~min}, 4^{\circ} \mathrm{C}\right)$, clear supernatant was taken and isopropanol was added. After incubation at room temperature for $10 \mathrm{~min}$, RNA pellet was precipitated by centrifugation $(12,000 \times \mathrm{g}, 10$ min, $4^{\circ} \mathrm{C}$ ). After quantitation, $4 \mu \mathrm{g}$ of total RNA was used for a semi-quantitative reverse transcriptase-polymerase chain reaction (RT-PCR). The generated CDNA was amplified by using primers for human bcl-2 (sense; TGC ACC TGA CGC CCT TCA C, anti-sense; AGA CAG CCA GGA GAA ATC AAA CAG), human bax (sense; ACC AAG AAG CTG AGC GAG TGT C, anti-sense; ACA AAG ATG GTC ACG GTC TGC C) and $\beta$-globin (sense; TTC TGA CAC AAC TGT GTT CAC TAG C, anti-sense; TAT TGG TCT CCT TAA ACC TGT CTT G). A $50 \mu \mathrm{l}$ of PCR mixture containing $1 \mu \mathrm{l}$ of the RT reaction was amplified with the following profile: $94^{\circ} \mathrm{C}$ for $1 \mathrm{~min}, 60^{\circ} \mathrm{C}$ for $1 \mathrm{~min}$, and $72^{\circ} \mathrm{C}$ for $1 \mathrm{~min}$, and the PCR products during the exponential phase of cDNA amplification were size-fractionated onto an $1.5 \%$ agarose gel and the gel was visualized with ethidium bromide.

\section{Protein analysis of bcl-2 and bax}

Cells $\left(1 \times 10^{6}\right)$ exposed to $0.5 \mathrm{mM}$ hydrogen peroxide for $0,2,4,6 \mathrm{~h}$ were collected, washed twice with PBS, and lysed in the sample buffer $(250 \mathrm{mM}$ Tris- $\mathrm{HCl}, \mathrm{pH}$ 6.8, 10\% Glycerol, $4 \%$ SDS, $2 \% \beta$-mercaptoethanol, 0.2 $\mathrm{mM}$ PMSF). The dissolved protein samples $(60 \mu \mathrm{g})$ heated at $95^{\circ} \mathrm{C}$ for $5 \mathrm{~min}$ were size-separated on the $12 \%$ Trisglycine polyacrylamide gel in SDS buffer and blotted on the nitrocellulose paper. Bcl-2 was visualized by $\mathrm{ECL}^{\mathrm{TM}}$ western blotting detection reagents (Pierce) using a combination of mouse anti-human bcl-2 (1:750) (SantaCruz) and anti-mouse peroxidase $(1: 1,000)$ (Boerhinger Mannheim). Bax was visualized using the same method except using mouse anti-human bax (1:750) (SantaCruz) as a primary antibody.

\section{Effect of cycloheximide (CHX)}

The cells $\left(1 \times 10^{6}\right)$ were treated with $0,0.1,0.5,1.5 \mathrm{mM}$ of hydrogen peroxide for $6 \mathrm{~h}$ in the presence of $0,0.5$, $1,5,10 \mu \mathrm{g} / \mathrm{ml}$ of $\mathrm{CHX}$, DNA was extracted from the treated cells as described early, electrophoresed on an $1.2 \%$ agarose gel, and visualized with ethidium bromide staining.

\section{Results}

Hydrogen peroxide-induced apoptosis in HL-60 cells

Flow cytometry of the cells stained with Annexin-V-Fluos showed that PS that are normally present in inner plasma membrane, was externalized at 0.5 and $1.5 \mathrm{mM}$ hydrogen peroxide treatment [Figure 1. A. (3), (4)]. Since some of Annexin-stained cells were found to react with propidium iodide, a stain for cell necrosis, a duplicate sample 
A
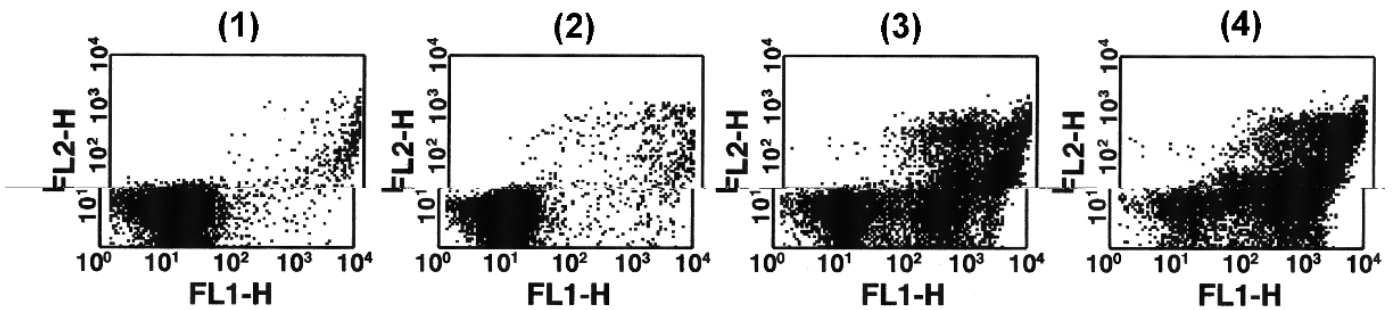

B

(1)

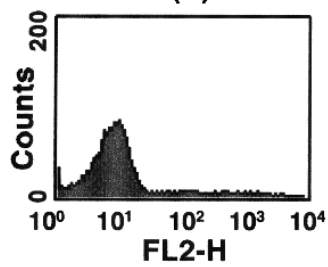

(2)



(3)



(4)

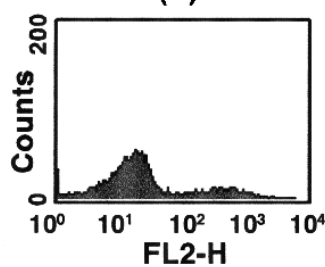

Figure 1. Flow cytometry analysis of $\mathrm{HL}-60$ cells after treatment with different concentrations of hydrogen peroxide for $6 \mathrm{~h}$. A. Dot plot analysis for annexin $(\mathrm{FL} 1-\mathrm{H})$ and propidium iodide (PI)(FL2-H) of control cells (1) and $0.1 \mathrm{mM}(2), 0.5 \mathrm{mM}(3)$, and $1.5 \mathrm{mM}$ hydrogen peroxide-treated cells (4) showed increased annexin-stained cells with increased hydrogen peroxide concentration. B. Histogram analysis for PI staining of control cells (1) and $0.1 \mathrm{mM}(2), 0.5 \mathrm{mM}(3)$, and $1.5 \mathrm{mM}$ hydrogen peroxide-treated cells (4) did not show significantly increased Pl-stained cells with increased hydrogen peroxide concentration.

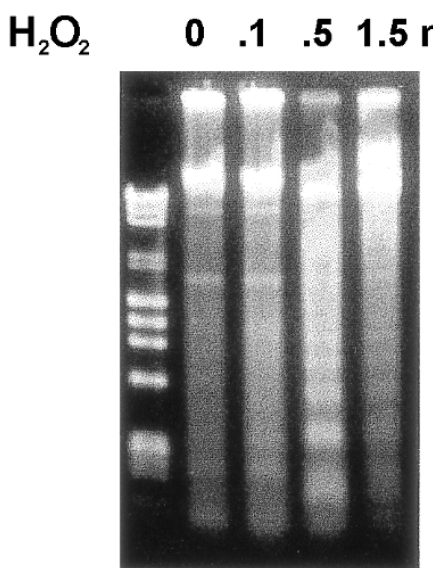

Figure 2. DNA ladder formation in $\mathrm{HL}-60$ cells treated with different concentrations of hydrogen peroxide for $6 \mathrm{~h}$ on an $1.2 \%$ agarose gel. DNA ladders indicative of internucleosomal DNA fragmentation were apparent with $0.5 \mathrm{mM}$ hydrogen peroxide treatment.

of the treated cells were stained with propidium iodide only to exclude the fluorescence overlapping. The cells treated with $0.5 \mathrm{mM}$ hydrogen peroxide showed only a minor staining by propidium iodide [Figure 1. B. (3)] and fluorescence observed in flow cytometry is mostly contributed by Annexin-stain. DNA fragmentation became obvious at $0.5 \mathrm{mM}$ hydrogen peroxide treatment (Figure 2). Cell cycle analysis also showed that apoptotic cells were markedly increased with $0.5 \mathrm{mM}$ hydrogen peroxide treatment (Figure $3 \&$ Table 1). Greater number of the $0.5 \mathrm{mM}$ hydrogen peroxide treated cells $(87 \%)$ were found in G0 G1 phase and lower in S and G2-M phases than control cells (Figure 3, Table 1).
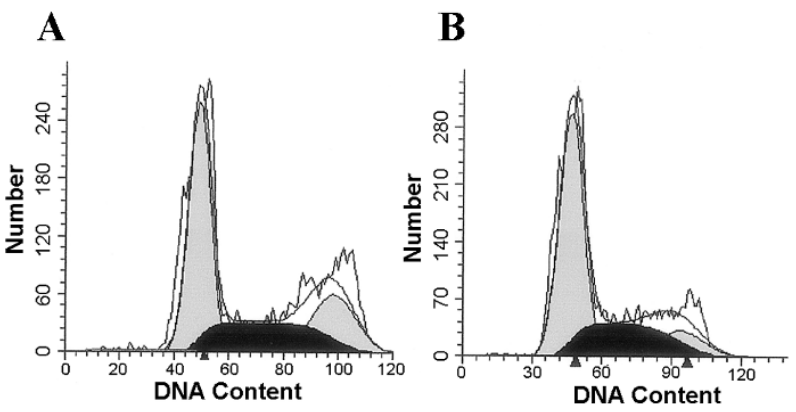

$$
\text { C }
$$

D
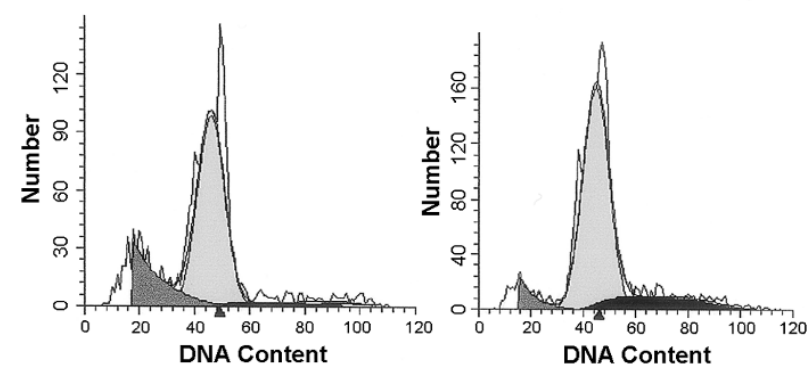

Figure 3. Cell cycle analysis after treatment with different concentrations of hydrogen peroxide for $6 \mathrm{~h}$. A. Control cells, B. $0.1 \mathrm{mM}$ hydrogen peroxidetreated cells, C. $0.5 \mathrm{mM}$ hydrogen peroxide-treated cells, D. $1.5 \mathrm{mM}$ hydrogen peroxide-treated cells. G0-G1 and G2-M cells are indicated as $\mathrm{S}$ cells as $\square$, apoptotic cells as 鮝.

$\mathrm{Bcl}-2$ and bax expression in hydrogen peroxideinduced apoptosis in HL-60 cells

The cellular level of bcl-2 mRNA exposed to $0.5 \mathrm{mM}$ hydrogen peroxide was decreased in a time-dependent 
Table 1. Effects of different concentrations of hydrogen peroxide on the cell cycle distribution in HL-60 cells

\begin{tabular}{ccrcc}
\hline \multirow{2}{*}{$\begin{array}{c}\text { Hydrogen } \\
\text { peroxide }(\mathrm{mM})\end{array}$} & \multicolumn{4}{c}{ Cell cycle distribution (\%) } \\
\cline { 2 - 5 } & $\mathrm{G} 0-\mathrm{G} 1$ & \multicolumn{1}{c}{$\mathrm{S}$} & $\mathrm{G} 2-\mathrm{M}$ & Apoptosis \\
\hline 0 & 49.20 & 24.95 & 25.85 & 2.55 \\
0.1 & 60.31 & 21.66 & 18.03 & 0.54 \\
0.5 & 87.40 & 9.40 & 3.20 & 21.79 \\
1.5 & 80.90 & 19.10 & 0.00 & 6.12 \\
\hline
\end{tabular}
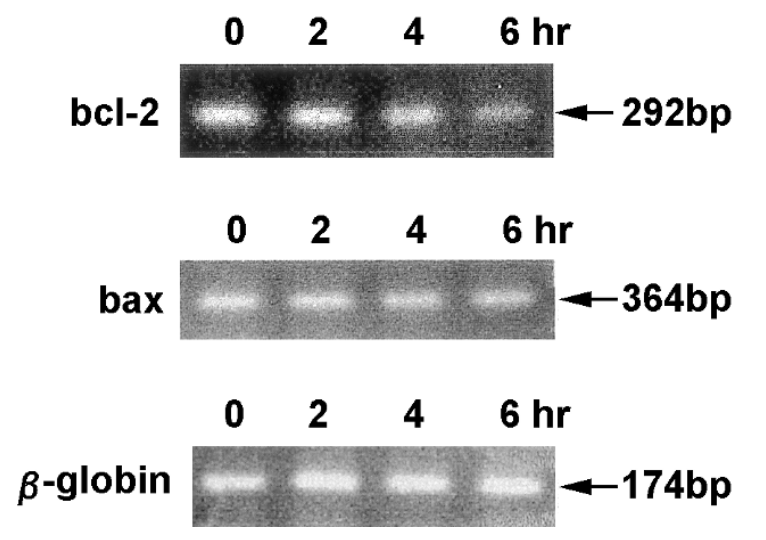

Figure 4. Time-based RT PCR analysis of $\mathrm{HL}-60$ cells after treatment of $0.5 \mathrm{mM}$ hydrogen peroxide on an $1.5 \%$ agarose gel. Bcl-2 mRNA decreased with time $(0,2,4,6 \mathrm{hr})$ whereas bax mRNA did not change. $\beta$-globin was shown as a control.
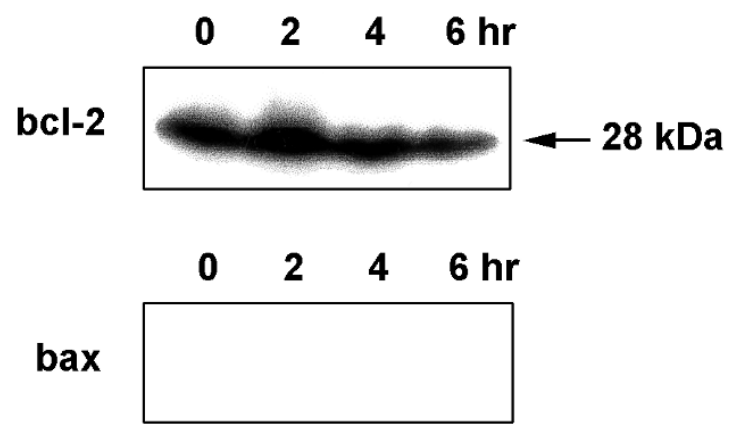

Figure 5. Time-based protein analysis of $\mathrm{HL}-60$ cells after treatment of 0.5 $\mathrm{mM}$ hydrogen peroxide on a $12 \%$ Tris-glycine polyacrylamide gel. Bcl-2 increased at $2 \mathrm{~h}(126 \%$ of $0 \mathrm{~h})$ and after then, decreased significantly $(93 \%$ and $70 \%$ of $0 \mathrm{~h}$, subsequently), whereas bax was not expressed. Image analysis was done by Scion Image beta 3B.

manner after $2 \mathrm{~h}$ whereas the level of bax mRNA was not affected (Figure 4). The level of bcl-2 protein was increased at $2 \mathrm{~h}$ and then decreased in a progressive manner whereas the expression of bax protein was not detected at all. (Figure 5).

\section{Effect of $\mathrm{CHX}$ on hydrogen peroxide-induced apoptosis in HL-60 cells}

Cycloheximide $(\mathrm{CHX})$ at 0.5 and $1 \mu \mathrm{g} / \mathrm{ml}$ concentrations did not prevent DNA fragmentation in the HL-60 cells

\section{$\mathrm{CHX}(\mu \mathrm{g} / \mathrm{ml})$ \\ $\mathrm{H}_{2} \mathrm{O}_{2}$}

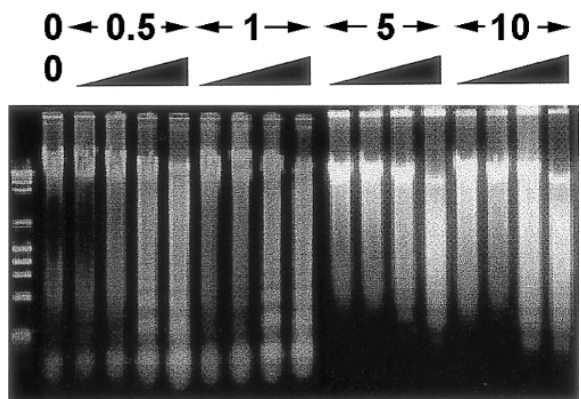

Figure 6. Effect of cycloheximide $(\mathrm{CHX})$ on hydrogen peroxide-mediated apoptosis in HL-60 cells. HL-60 cells were treated with different concentrations $(0,0.1,0.5,1.5 \mathrm{mM}$, represented as $)$ of hydrogen peroxide in the presence of different concentrations $(0,0.5,1,5,10 \mu \mathrm{g} / \mathrm{ml})$ of $\mathrm{CHX}$. DNA ladders were observed with 0.5 and $1.5 \mathrm{mM}$ hydrogen

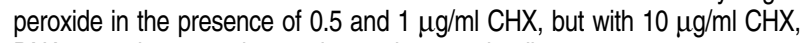
DNA smearing was observed even in control cells.

exposed to 0.5 and $1.5 \mathrm{mM}$ hydrogen peroxide. Rather, DNA smearing indicative of necrosis was shown even in control cells at high concentration $(10 \mu \mathrm{g} / \mathrm{ml})$ of $\mathrm{CHX}$ (Figure 6).

\section{Discussion}

Exposure of HL-60 cells to hydrogen peroxide, induced cell death in a dose-dependent manner. Apoptotic cells were abundant at low concentration $(0.5 \mathrm{mM})$ whereas necrotic as well as apoptotic cells were observed at high concentration (1.5 mM). Apoptosis is a physiological reaction occurring even in control cells as shown in cell cycle analysis. It can occur at any stage of cell cycle and one apoptotic stimulus can arrest more than one stage of cell cycle (Schwartz et al., 1995). An increase of cells in G1 stage and a decrease in S and G2-M stage indicate $\mathrm{G} 1$ to $S$ arrest. Among the cell cycle regulators that control $\mathrm{G} 1$ to $S$ transition, p53 is not expressed in $\mathrm{HL}$ 60 cells and therefore, this arrest occurred through the p53-independent pathway. There are number of proapoptotic molecules participating in $\mathrm{G} 1$ to $\mathrm{S}$ transition, e.g., p15, p16, p18, p19, p21, p27, and p57. Among them, p21 is known to be controlled by p53 (Nguyen, L. $Q$ et al., 1998). Within the cell cycle, cyclin/cdk complex induces phosphorylation of retinoblastoma $(\mathrm{Rb})$ protein. Once $\mathrm{Rb}$ is phosphorylated, it is dissociated from transcription factor E2F and free E2F can induce transcription of other proteins that are necessary for further progression of cell cycle. Although it is not clear how hydrogen peroxide affects $\mathrm{G} 1$ arrest, quinone, a chemotherapeutic agent, is reported to induce the apoptosis, and increase ROS and p21 within the cell (Qui et al., 1998). Cell cycle analysis and DNA fragmentation study both showed hydrogen peroxide-induced apoptosis in $\mathrm{HL}-60$ cells at $0.5 \mathrm{mM}$ concentration accompanied with a slight increase of bcl-2 protein at $2 \mathrm{~h}$ and then the 
level falls significantly below controls. Anti-apoptotic mechanism of bcl-2 related with oxidants is that bcl-2 itself is a pro-oxidant rather than an anti-oxidant. As the level of pro-oxidant in the cell increases, the level of intrinsic cellular anti-oxidant also rises through bcl-2 mediated reaction and cells become resistant to oxidant and oxidant-induced apoptosis (Steinman, 1995). Bcl-2 is known to suppress the apoptosis by controlling the membrane potential of mitochondria and/or preventing calcium depletion of endoplasmic reticulum (Distelhorst et al., 1996; Shimizu et al., 1998). Bcl-2 has been demonstrated to prevent apoptosis only at low concentration of hydrogen peroxide $(0.1 \mathrm{mM})$. The cellular damage to strong oxidant stimuli like hydrogen peroxide appears to be dose dependent: the process is a continuum from apoptosis at low concentration to necrosis at high concentration (Gardner et al., 1997). In our study, $0.5 \mathrm{mM}$ hydrogen peroxide induced the decrease of bcl-2 protein as well as bcl-2 mRNA. Bcl-2 as an anti-apoptotic protein forms homoor hetero-dimer with pro-apoptotic protein of bcl-2 family within the cell and their ratio eventually determines whether the cell takes into the apoptotic pathway. Bax is a known pro-apoptotic protein in bcl-2 family. Interestingly, however, bax protein is not expressed in HL-60 cells albeit its mRNA is expressed and is not changed with hydrogen peroxide treatment. Since bcl-2 is known to form a heterodimer with its counter-protein, absence of bax in HL-60 cells suggests that there may present another pro-apoptotic protein. As one of those candidates, expression of bak was studied, but was not detected either (data not shown). hydrogen peroxide-induced apoptosis of HL-60 cells is not prevented by CHX. Since $\mathrm{CHX}$ is a nonspecific translation inhibitor, a possible involvement of other proteins in apoptotic processes can be ruled out. The possibility of apoptosis by $\mathrm{CHX}$ itself (Gong et al., 1993) is excluded by using CHX alone in control cells, which does not induce apoptosis.

In conclusion, this study presents the mechanism of hydrogen peroxide-induced apoptosis in $\mathrm{HL}-60$ cells, which is regulated by decreased bcl-2 without the change of bax at the transcription level and does not need a new protein synthesis.

\section{References}

Agarwal, N. and Mehta, K. (1997) Possible involvement of $\mathrm{Bcl}-2$ pathway in retinoid $\mathrm{X}$ receptor alpha-induced apoptosis of HL-60 cells. Biochem. Biophys. Res. Comm. 230: 251-253

Distelhorst, C. W., Lam, M. and McCormick, T. S. (1996) Bcl-
2 inhibits hydrogen peroxide-induced ER Ca2+ pool depletion. Oncogene 12: 2051-2055

Gardner, A. M., Xu, F. H., Fady, C., Jacoby, F. J., Duffey, D. C., Tu, Y. and Lichtenstein, A. (1997) Apoptotic vs. nonapoptotic cytotoxicity induced by hydrogen peroxide. Free Radic. Biol. Med. 22: 73-83

Gong, J., Li, X. and Darzynkiewicz, Z. (1993) Different patterns of apoptosis of HL-60 cellls induced by cycloheximide and camptothecin. J. Cell Physiol. 157: 263-270

Gorman, A., McGowan, A. and Cotter, T. G. (1997) Role of peroxide and superoxide anion during tumour cell apoptosis. FEBS Lett 404: 27-33

Hockenbery, D. M., Oltvai, Z. N., Yin, X. M., Milliman, C. L. and Korsmeyer, S. J. (1993) Bcl-2 functions in an antioxidant pathway to prevent apoptosis. Cell 75: 241-251

Nguyen, L. Q. Jameson, J. L. (1998) Principles of Molecular Medicine (J. L. Jameson ed.) pp65-72, Humana Press, New Jersey

Kerr, J. F. R., Wyllie, A. H. Curie, A. R. (1972) Apoptosis: A basic biological phenomenon with wide ranging implications in tissue kinetics. Br. J. Cancer 26: 239-257

Lennon, S. V., Martin, S. J. and Cotter, T. G. (1991) Dosedependent induction of apoptosis in human tumour cell lines by widely diverging stimuli. Cell Prolif. 24: 203-214

Mengubas, K., Riordan, F. A., Hoffbrand, V. and Wickremasinghe, G. (1996) Co-ordinated downregulation of bcl-2 and bax expression during granulocytic and macrophage-like differentiation of the HL60 premyelocytic leukemia cell line. FEBS Lett 394: 356-360.

Qui, X., Schonthal, A. H. and Cadenas, E (1998) Anticancer quinones induce pRB-preventable $\mathrm{G} 2 / \mathrm{M}$ cell cycle arrest and apoptosis. Free Radic. Biol. Med. 15: 848854.

Schwartz, L. M. and Osborne, B. A. (1995) Cell Death, Volume 46 (L. Wilson, Matsudaira, and Paul, eds.), pp77-97, Academic Press, San Diego

Shimizu, S., Eguchi, Y., Kamiike, W., Funahashi, Y., Mignon, A., Lacronique, V., Matsuda, H. and Tsujimoto, Y. (1998) Bcl2 prevents apoptotic mitochondrial dysfunction by regulating proton flux. Proc. Natl. Acad. Sci. U. S. A. 95: 1455-1459.

Shimizu, T. and Pommier, Y. (1996) DNA fragmentation induced by protease activation in p53-null human leukemia HL60 cells undergoing apoptosis following treatment with the topoisomerase I inhibitor Campotothecin: Cell-free system studies. Exp. Cell Res. 226: 292-301.

Steinman, H. M. (1995) The Bcl-2 oncoprotein functions as a pro-oxidant. J. Biol. Chem. 270: 3487-3490.

Ueda, N. and Shar, S. V. (1992) Endonuclease-induced DNA damage and cell death in oxidant injury to renal tubular epithelial cells. J. Clin. Invest. 90: 2593-2597. 